\title{
GESTÃO DA DRENAGEM URBANA NA CAPITAL DO ESTADO DO ESPÍRITO SANTO
}

\author{
URBAN DRAINAGE MANAGEMENT IN THE CAPITAL OF THE STATE OF ESPÍRITO SANTO
}

\author{
Vanilda da Conceição Lucas dos Reisa ${ }^{\mathrm{a}}$, Jonio Ferreira de Souzaa, Fábio Márcio Bisi Zorzala , Silvia \\ Fernandes Rocha ${ }^{a}$, Vergínia Januário dos Reis Rocha ${ }^{b}$
}

vanildalucas@gmail.com, joniosouza1@gmail.com, fzorzal@ifes.edu.br, silfroc@gmail.com, verginia7@gmail.com

alnstituto Federal do Espírito Santo, bServidora da Prefeitura Municipal da Serra/ES

Submissão: 26 de outubro de 2020 Aceitação: 26 de novembro de 2020

\section{Resumo}

A urbanização das cidades tem diminuído a infiltração das águas pluviais e aumentado o escoamento superficial, proporcionando alagamentos, deslizamentos de encostas e poluição de corpos hídricos. Considerando que o serviço público de Drenagem e Manejo de águas pluviais urbanas foi estabelecido, pela Lei $n^{\circ}$ 11.445/2007, como um componente do saneamento básico com titularidade municipal, urge a necessidade de se verificar o empenho da gestão municipal para evitar os problemas de drenagem. Assim, com base em revisão bibliográfica e documental, este trabalho promove uma investigação acerca da gestão municipal de Drenagem e Manejo de águas pluviais urbanas no município de Vitória/ES, possibilitando descrever a infraestrutura do sistema implantado, os aspectos legais existentes, a estrutura organizacional empregada, os recursos humanos disponíveis e os recursos financeiros aplicados no período de 2014 a 2017. O resultado demonstra que Vitória possui um sistema de drenagem composto por $285,48 \mathrm{~km}$ de redes, quatro estações de bombeamento de águas pluviais, seis reservatórios in line e um off line. Os principais instrumentos legais identificados compreendem o Plano Municipal de Saneamento Básico, que atualizou o Plano Diretor de Drenagem Urbana, as diretrizes do Plano Diretor Urbano relativas às taxas de impermeabilização, e o Manual de Drenagem. Três secretarias municipais acumulam atribuições para a gestão e o gerenciamento da componente drenagem urbana, ocorrendo pouca integração na realização das atividades de planejamento, implantação, operação, manutenção e monitoramento. O estudo demonstra, ainda, que apenas dois servidores atuam exclusivamente com drenagem e que os recursos financeiros aplicados em 2017 representam $0,3 \%$ das despesas municipais ocorridas no mesmo ano. Conclui-se que o desempenho da gestão de drenagem no Município apresentou um recuo nos anos analisados.

Palavras-chave: Drenagem Urbana, Infraestrutura de drenagem, Recursos humanos e financeiros aplicados à drenagem.

\section{Abstract}

The urbanization of cities reduces the infiltration of rainwater and increases runoff, providing flooding, landslides and pollution of water bodies. Considering that Drainage and Management of urban rainwater service was established, by Law no 11445 / 2007, as an axis of basic sanitation with municipal ownership, there is an urgent need to verify the commitment of the municipal management to avoid drainage problems. Thus, based on a bibliographic and documentary review, this work promotes an investigation about the municipal management of drainage and management of urban rainwater in the municipality of Vitória / ES. Making it possible to describe the infrastructure of the implemented system, the existing legal aspects, the organizational structure, the human resources available and the financial resources applied in the period from 2014 to 2017. The result shows Vitória has a drainage system composed of $285.48 \mathrm{~km}$ of networks, four rainwater-pumping stations, six in-line reservoirs and an off line. The main legal instruments identified comprise the municipal basic sanitation plan, which updated the urban drainage master plan, the guidelines 
of the urban master plan, relating to waterproofing rates and the drainage manual. The drainage attributions are distributed in three municipal departments and have little integration in the planning, execution, operation, maintenance and monitoring activities. The study also shows that only two civil servants work exclusively with drainage and that the financial resources applied in 2017 represent $0.3 \%$ of municipal expenses that occurred in the same year. It concludes that the performance of drainage management in the municipality has decreased in the last years of analysis.

Keywords: Urban Drainage, drainage infrastructure, human and financial resources applied to drainage

\section{INTRODUÇÃO}

A maioria dos municípios brasileiros enfrenta desafios para apresentar soluções aos problemas originados pelas águas pluviais (TUCCI, 2012). Muitos desses problemas perpassam pela gestão municipal, cuja estrutura e ações destinadas à drenagem e manejo das águas pluviais (DMAP) recebem críticas feitas tanto pela mídia, quanto pelos munícipes, que a cada chuva intensa têm perdido bens e, até mesmo, compromissos de toda ordem, por não conseguirem se deslocar devido aos alagamentos.

No âmbito das políticas públicas desenvolvidas para resolução desse problema, observa-se que a drenagem e manejo das águas pluviais urbanas são um componente regido pela política de saneamento básico, e sua gestão deve se balizar também pelas políticas de recursos hídricos, de meio ambiente e de uso e ocupação do solo (BRASIL,1995).

Como instrumento da política de saneamento básico, a Lei Federal ํo 11.445/2007 estabeleceu que os municípios brasileiros elaborassem e implementassem 0 Plano Municipal de Saneamento Básico, contemplando os quatro componentes: drenagem e manejo de águas pluviais, abastecimento de água, esgotamento sanitário e manejo de resíduos sólidos (BRASIL, 2007).

No entanto, Martins (2012) expõe que a drenagem urbana ainda é considerada menos nobre do que abastecimento de água e coleta de esgotos sanitários, não havendo interesse das concessionárias de água e esgoto, nem mesmo das empresas que prestam serviços relacionados a resíduos sólidos em agregar a drenagem urbana em seu quadro de serviços e, dessa forma, se mantém como um serviço prestado pela administração pública direta por meio de sua estrutura organizacional.
O plano de saneamento básico, o plano diretor urbano e os planos de bacias hidrográficas devem ser considerados como instrumentos de planejamento que definem diretrizes e atuam de forma alinhada com o arcabouço legal municipal na gestão da drenagem e manejo das águas pluviais. Entretanto, muitos municípios brasileiros ainda não elaboraram esses instrumentos.

O desenvolvimento da gestão pública na área de recursos hídricos, na qual também se insere a drenagem e manejo das águas pluviais, necessita de profissionais qualificados, tanto para a execução como para a tomada de decisões (TUCCI; HESPANHOL; NETTO, 2001). Esses autores acrescentam que a maioria dos profissionais que atua na área adquiriu sua capacitação no próprio trabalho e apenas um grupo menor obteve conhecimentos por meio de cursos de especialização, mestrado e/ou doutorado.

A sustentabilidade financeira na gestão da drenagem e manejo das águas pluviais é requerida para permitir recursos na operação e manutenção, bem como investimentos para implantação dos sistemas (BAPTISTA; NASCIMENTO, 2002).

Considerando a necessidade de identificar pontos para melhoria na gestão pública municipal da drenagem urbana, este artigo tem como objetivo analisar a gestão da drenagem na capital do estado do Espírito Santo, abordando os aspectos da estrutura organizacional, capacidade administrativa dos atores municipais atuantes em drenagem, recursos investidos nos anos de 20142017 e o arcabouço legal existente.

\section{FUNDAMENTAÇÃO TEÓRICA}

\section{Princípios, sistemas, dispositivos e normas de drenagem}

A drenagem urbana tradicional, imbuída do princípio higienista, teve início no Brasil em 1850 
com coleta e afastamento imediato das águas pluviais, no intuito de preservar a saúde populacional e acabar com o incômodo que essas águas poderiam provocar (CHRISTOFIDIS et al., 2019).

A engenharia permitiu que esse transporte hídrico ocorresse em sistema unitário, sistema separador parcial e sistema separador absoluto. No sistema unitário ou combinado, a rede é construída para coleta e condução conjunta de águas pluviais, esgoto doméstico e despejos industriais. No sistema separador parcial ou misto, ocorre a coleta e transporte de esgoto doméstico, despejos industriais e apenas parcela de águas pluviais, pois as provenientes de quintais, vias públicas, jardins e demais áreas não pavimentadas não são transportadas. Por sua vez, o sistema separador absoluto, instituído em
1912 no Brasil, permite que águas pluviais sejam coletadas e transportadas por uma rede exclusiva, enquanto 0 esgoto doméstico e despejos industriais adotam uma rede totalmente independente (NUVOLARI, 2011).

De acordo com os dados do SNIS-AP (2018), no universo de 3.603 dos 5.570 municípios brasileiros, o sistema exclusivo para drenagem (separador absoluto) ocorre em $54,7 \%$, enquanto o sistema unitário está presente em $24,6 \%$ e em 17,6\% não existe sistema de drenagem, como mostrado na Figura 1.

Righetto (2009) e Nuvolari (2011) alertam que os sistemas exclusivos para drenagem acabam recebendo contribuição de esgoto sanitário devido às ligações clandestinas. Neves e Tucci (2011) acrescentam o carreamento de resíduos sólidos para o sistema de drenagem.

\section{Figura 1: Municípios participantes do SNIS-AP 2018 e seus sistemas de drenagem}

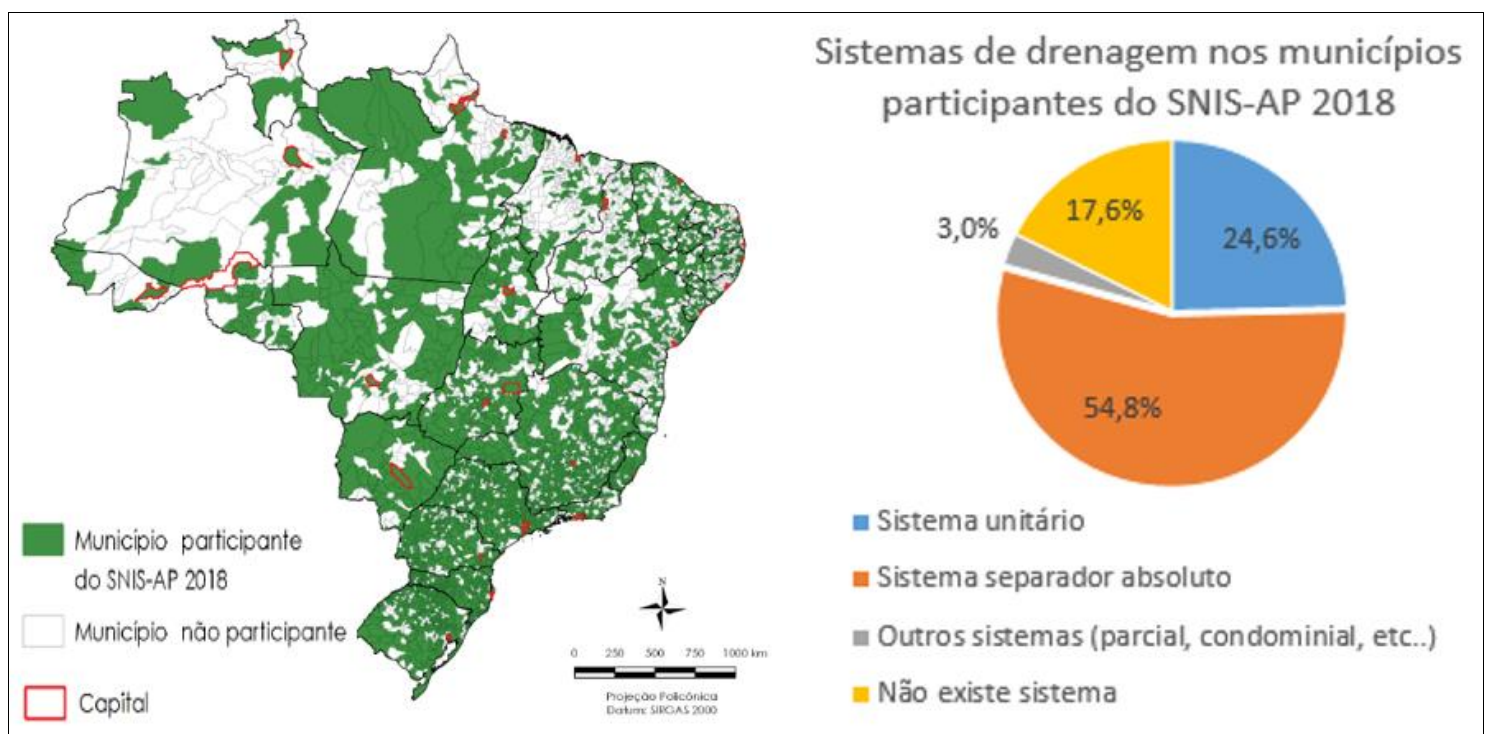

Fonte: Elaboração própria a partir de dados do SNIS-AP (2018).

De acordo Tucci (2000) e Santos (2016), o sistema convencional de drenagem urbana é composto por um conjunto de dispositivos, tais como as guias (meios-fios), sarjetas, sarjetões, bocas-de-lobo, tubos de ligações, caixas de passagens, redes coletoras, poços de visitas, galerias, estações de bombeamento e condutos forçados. Esses dispositivos compõem a Microdrenagem, definida como o sistema inicial de condutos de águas pluviais em nível de loteamento ou rede primária, e a Macrodrenagem, responsável pelo escoamento final por grandes galerias, canais e rios.

Todavia, essa expulsão rápida das águas pluviais provoca elevação dos picos de cheias nos cursos de água a jusante e a diminuição do tempo de concentração, agravando a situação das cidades, dos cidadãos e das águas (CHRISTOFIDIS et al., 2019).

Portanto, em substituição e/ou 
complementação ao princípio higienista, inicia-se no Brasil, em 1990, a utilização de dispositivos ligados ao princípio sustentável com soluções alternativas, compensatórias e ambientais que agem em conjunto com as estruturas convencionais (CRUZ et al., 2007; AGOSTINHO; POLETO, 2012).

Assim, o manejo das águas pluviais passou a adotar princípios que ampliam o olhar para a dinâmica das águas no ciclo hidrológico, propiciando a redução do escoamento superficial das águas pluviais, com a indução à maior infiltração e percolação nos solos com sentido de controle quantitativo, qualitativo e de regularização da oferta hídrica; inclusive, com a adoção de medidas de retenção de águas, como as obras alternativas para redução do pico de cheias e da velocidade das águas (SOUZA et al., 2012).

Dentre os sistemas sustentáveis (Sustainable Urban Drainage Systems - SUDS), os mais utilizados são: pavimento permeável e semipermeável; reservatórios de detenção e retenção; trincheiras de infiltração; vala e valeta de infiltração; poço de infiltração; telhado verde; e faixas gramadas (POLETO, 2011).

Para as diretrizes nacionais de saneamento básico (Lei no 11.445/2007), a drenagem e manejo das águas pluviais urbanas (DMAPU) são constituídos por atividades, infraestruturas e instalações operacionais de drenagem de águas pluviais, transporte, detenção ou retenção para o amortecimento de vazões de cheias, tratamento e disposição final das águas pluviais drenadas, contempladas a limpeza e a fiscalização preventiva de redes (BRASIL, 2007).

Vários autores, como Tucci (2005), Righetto (2009) Souza (2013) e Miguez et al. (2015), descrevem que o planejamento, gestão e operação da DMAPU utilizam medidas estruturais e medidas não estruturais. Esses autores definem que as medidas estruturais contemplam instalações, dispositivos e elementos físicos, com a finalidade principal de reter ou transportar deflúvios gerados na bacia e propiciar a infiltração localizada. Essas medidas estruturais são classificadas em extensivas, quando agem no contexto global da bacia, e intensivas, quando atuam numa escala menor.

Como medidas não estruturais, encontramse as ações que procuram disciplinar a ocupação territorial e o comportamento de consumo das pessoas e das atividades econômicas. Essas medidas compreendem normas, incentivos fiscais, programas e planos de ação, apresentando menor custo que as medidas estruturais que requerem instalações de estruturas físicas.

Apesar dos demais sistemas que compõem o saneamento básico (manejo de resíduos sólidos, abastecimento de água e esgotamento sanitário) apresentarem normas técnicas nacionais específicas para elaboração de projetos, verifica-se uma carência normativa para os projetos de drenagem urbana. Nesta direção, constata-se que, na Associação Brasileira de Normas Técnicas (ABNT, c2019), as normativas mais próximas ao tema estão voltadas para drenagem agrícola (NBR 14.143/1998, $14.144 / 1998$ e 14.145/1998), para instalações prediais de águas pluviais (NBR 10.844/1989) e para procedimentos de execução de valas para assentamento de tubulação de água, esgoto ou drenagem urbana (NBR 12.266/1992), ficando aparente a lacuna existente em normas que estabelecem diretrizes para elaboração e implementação de projetos de drenagem urbana. Como consequência, a terminologia e os critérios variam de município para município e costumam fazer parte dos planos utilizados como instrumentos de gestão das águas.

\section{Instrumentos de gestão das águas}

De acordo com Souza (2002), o planejamento é a preparação para a gestão, considerando que o planejamento é um instrumento para gerir o futuro com estabelecimento de metas e prazos, e gerir é administrar uma situação presente, cujas necessidades e os recursos disponíveis são conhecidos.

Corroborando com esses conceitos, as políticas públicas fomentam a necessidade de se definir planos para gestão de diferentes temas. É o que ocorre com as Políticas de Recursos Hídricos e de Saneamento que estabelecem, como instrumentos de gestão, os Planos de bacias hidrográficas e os Planos de saneamento básico, respectivamente. Inclusive, o Plano Diretor também é estabelecido como um instrumento de Política Urbana.

Assim, surgiram os Planos Diretores de Drenagem Urbana (PDDU), complementando os 
Planos Diretores Municipais (PDM) e os Planos de Drenagem e Manejo de Águas Pluviais Urbanas (PDMAPU), integrando os Planos Municipais de Saneamento Básico (PMSB).

Vale esclarecer que os Planos Diretores Municipais (PDM), denominados, também, de Planos Diretores Urbanos (PDU) em algumas cidades, são obrigatórios para municípios com mais de vinte mil habitantes, integrantes de regiões metropolitanas e aglomerações urbanas, integrantes de áreas de especial interesse turístico e os inseridos na área de influência de empreendimentos ou atividades com significativo impacto ambiental de âmbito regional ou nacional.

Dados do perfil dos municípios brasileiros de 2018 indicam que o PDM foi elaborado em $90,1 \%$ dos municípios com mais de 20 mil habitantes e em $33,6 \%$ dos municípios com menos de 20 mil habitantes (IBGE, 2019), contudo, não se tem informação como o componente drenagem e manejo de águas pluviais urbanas foi abordado.

De acordo com o SNIS (2018), dos 3.603 municípios respondentes dos 5.570 municípios brasileiros, 719 municípios apresentavam PDMAPU como parte do PMSB, sendo que 14 deles são capixabas. Enfatiza-se que nem todos os PMSB abordam os componentes drenagem e manejo de águas pluviais urbanas.

Com relação aos Planos de Bacias do Estado do Espírito Santo, a AGERH (2020) apresenta, em seu site, os 13 planos de bacia hidrográfica já elaborados e indica que o plano de bacia que falta para cobertura de todo o estado encontra-se em elaboração.

\section{Estrutura organizacional de gestão das águas}

A gestão das águas envolve diretamente a gestão dos recursos hídricos e a gestão do saneamento básico, que contempla a componente drenagem e manejo das águas pluviais urbanas.

Para a gestão dos recursos hídricos, a estrutura organizacional é definida pelos Sistemas Nacional e Estadual de Gerenciamento de Recursos Hídricos (SINGREH e SIGERH), regidos pelas políticas federal (Lei no 9.433/1997) e estaduais, sendo no Espírito Santo por meio da Lei no 10.179/2014 (BRASIL, 1997; ESPÍRITO SANTO, 2014). O Quadro 1 apresenta de forma sucinta a estrutura responsável pela formulação e pela implementação da Política de Recursos
Hídricos, com enfoque no Espírito Santo.

O Estado do Espírito Santo possui 14 comitês de Bacias estaduais, com nenhuma Agência de Bacia consolidada, e apenas 1 Comitê de Bacia Interestadual do Rio Doce, oriundo de Minas Gerais. Os comitês são organismos colegiados com atribuição de caráter normativo, consultivo e deliberativo para a formulação da política, e compostos por representantes do setor público, dos usuários de água e da sociedade civil organizada (AGERH, 2020).

A estrutura organizacional para gestão do saneamento básico, por sua vez, costuma se balizar nos modelos internacionais para organização e regulação da área e se ajusta às diretrizes do marco legal e regulatório do saneamento básico no Brasil, conforme Lei $n^{\circ}$ 11.445/2007 (BRASIL, 2007).

Ao considerar a titularidade municipal para planejamento, gerenciamento, operação e manutenção dos serviços públicos de saneamento básico, devem-se atentar aos fundamentos da Administração Pública citados por autores como Andrade e Rossetti (2006) e Chiavenato (2007). Esses autores enfatizam que a Administração Pública pode realizar suas atividades de forma direta, por meio de seus próprios órgãos, ou de forma indireta, por meio de autarquias e fundações públicas, regidas pelo direito público, bem como por empresas públicas e sociedade de economia mista, regidas pelo direito privado.

e acordo com Barbieri (2016), a Administração Pública pode outorgar por lei a transferência de sua titularidade do serviço público, bem como delegar a execução do serviço por contrato. A autora exemplifica que empresas públicas e sociedades de economia mista podem receber a titularidade do serviço público, quando constituídas por lei para esse fim, mas, também, ser meras executoras dos serviços que lhes sejam transferidos por contrato.

A execução de serviços públicos pode ser delegada inclusive ao particular mediante processo de licitação regido pela Lei federal $n^{-}$ 8.666/1993 (BRASIL, 1993). Acrescenta-se que a concessão de serviços públicos, precedida ou não da execução de obra pública, é prevista na Lei federal o 8.987/1995 (BRASIL, 1995), permitindo delegação mediante licitação à pessoa jurídica ou consórcio de empresas que demonstre 
capacidade para seu desempenho por sua conta e risco e por prazo determinado.

Nas concessões comuns, as concessionárias fazem os investimentos necessários e assumem os riscos da exploração da atividade, remunerando-se exclusivamente por meio da cobrança de tarifas dos usuários e/ou da exploração de eventuais receitas acessórias. Ao final do contrato, os ativos concedidos retornam para o governo cedente, que poderá administrálos diretamente ou concedê-los novamente. Nas concessões patrocinadas, um tipo de parcerias público-privadas (PPP), regidas pela Lei federal 11.079/2004 (BRASIL, 2004), ocorre uma contraprestação pecuniária do parceiro público ao parceiro privado, como forma de garantir uma tarifa mais baixa ou, até mesmo, não ser cobrada tarifa à população.

\section{Quadro 1: Estrutura organizacional para gestão dos Recursos Hídricos no ES}

\begin{tabular}{|c|c|c|c|c|}
\hline \multirow[b]{2}{*}{ Âmbito } & \multicolumn{2}{|c|}{ FORMULAÇÃO DA POLÍTICA } & \multicolumn{2}{|c|}{ IMPLEMENTAÇÃO DA POLÍTICA } \\
\hline & $\begin{array}{l}\text { Organismo } \\
\text { Colegiado }\end{array}$ & $\begin{array}{c}\text { Administração } \\
\text { direta }\end{array}$ & $\begin{array}{c}\text { Poder } \\
\text { Outorgante }\end{array}$ & $\begin{array}{l}\text { Entidade da } \\
\text { Bacia }\end{array}$ \\
\hline NACIONAL & $\begin{array}{c}\text { Conselho } \\
\text { Nacional de } \\
\text { Recursos } \\
\text { Hídricos - CNRH } \\
\text { Comitês de } \\
\text { Bacias } \\
\text { Interestaduais }\end{array}$ & $\begin{array}{l}\text { Ministério do } \\
\text { Governo } \\
\text { (MDR/SNSH) }\end{array}$ & $\begin{array}{l}\text { Entidade } \\
\text { Federal } \\
\text { (ANA) }\end{array}$ & $\begin{array}{l}\text { Agências de } \\
\text { Bacias Federais }\end{array}$ \\
\hline ESTADUAL & $\begin{array}{c}\text { Conselho } \\
\text { Estadual de } \\
\text { Recursos } \\
\text { Hídricos - CERH } \\
\text { Comitês de } \\
\text { Bacias Estaduais }\end{array}$ & $\begin{array}{l}\text { Secretarias de } \\
\text { Estado } \\
\text { (SEAMA) }\end{array}$ & $\begin{array}{l}\text { Entidades } \\
\text { Estaduais } \\
\text { (AGERH) }\end{array}$ & $\begin{array}{l}\text { Agências de } \\
\text { Bacias Estaduais }\end{array}$ \\
\hline $\begin{array}{l}\text { Obs.: } \\
\text { MDR - Ministério } \\
\text { SNSH - Secretaria } \\
\text { SEAMA - Secretar } \\
\text { ANA - Agência Na } \\
\text { AGERH - Agência }\end{array}$ & $\begin{array}{l}\text { senvolvimento Regio } \\
\text { nal de Segurança Híd } \\
\text { dual de Meio Ambie } \\
\text { de Águas E Saneame } \\
\text { ual de Recursos Hídric }\end{array}$ & $\begin{array}{l}\text { e Recursos Hídricos } \\
\text { o Básico } \\
\text { do Espírito Santo }\end{array}$ & spírito Santo & \\
\hline
\end{tabular}

Fonte: Elaboração própria.

Recorda-se que a Lei federal $\mathrm{n}^{\circ}$ 11.107/2005 (BRASIL, 2005) estabelece critérios para que os entes federados constituam e contratem consórcios públicos ou firmem convênio de cooperação para a realização de objetivos de interesse comum, como os serviços públicos de saneamento básico, ficando dispensada de licitação a prestação do serviço por empresa pública ou de economia mista de um dos entes, com a devida assinatura de contrato de programa entre ela e o titular do serviço.

Segundo Faria et al. (2005), a participação privada na área de saneamento básico pode ocorrer por diversas modalidades: contratos de administração ou de gestão; arrendamentos; vendas de participação minoritária; concessões parciais do tipo BOT (Build, Operate and
Transfer); concessões plenas; parcerias públicoprivadas (PPP); ou abertura de capital de companhias estatais. Muitas dessas modalidades já são praticadas hoje no Brasil.

Portanto, diversos arranjos podem ser configurados para estabelecer a estrutura organizacional do saneamento básico no Brasil, especialmente quando se considera que os quatro componentes (água, esgoto, resíduos sólidos e drenagem urbana) podem ser organizados de formas diferentes.

Essa forma variada de prestação dos serviços públicos de saneamento básico pode ser percebida com os dados do SNIS (2018) (Tabela 1). Nota-se que, dos municípios respondentes, a maioria tem seus serviços públicos de abastecimento de água e esgotamento sanitário 
prestados por sociedade de economia mista, em geral, as companhias estaduais de água e esgoto criadas a partir da década de 1960. Quanto aos componentes esgotamento sanitário, drenagem urbana e resíduos sólidos, observa-se maior atuação na prestação dos serviços pela Administração Pública direta, mesmo que a etapa de execução possa estar terceirizada. Não obstante, autarquias, empresas públicas, sociedade de economia mista, empresas privadas e até organizações sociais são vistas como formas de prestação de serviços públicos de saneamento básico no Brasil.

Especificamente na componente drenagem urbana, constata-se na Tabela 1 uma atuação majoritária da Administração Pública direta, seguida bem distante por autarquias e empresas públicas.

Tabela 1: Forma de prestação dos serviços de saneamento em municípios no Brasil

\begin{tabular}{|l|r|r|r|r|r|r|}
\hline \multirow{2}{*}{$\begin{array}{c}\text { Forma de prestação dos } \\
\text { serviços }\end{array}$} & \multicolumn{6}{|c}{ Número de formas de prestação de serviços por } \\
& componente de saneamento, em municípios brasileiros \\
\cline { 2 - 8 } & A\&E & Água & Esgoto & Drenagem & Resíduos & \multicolumn{1}{c}{ Total } \\
\hline Administração pública direta & 295 & 282 & 419 & 3.561 & 3.260 & 7.817 \\
\hline Autarquia & 318 & 202 & 1 & 37 & 79 & 637 \\
\hline Empresa pública & 54 & 29 & 0 & 4 & 106 & 193 \\
\hline Sociedade de Economia Mista & 1.357 & 2.487 & 0 & 0 & 23 & 3.867 \\
\hline Empresa Privada & 91 & 84 & 5 & 0 & 0 & 180 \\
\hline Organização Social & 0 & 3 & 0 & 0 & 0 & 3 \\
\hline
\end{tabular}

Fonte: Elaboração própria a partir de dados do SNIS (2018).

A Lei federal no 11.445/2007 (BRASIL, 2007) estabelece que, independentemente da modalidade de prestação do serviço público de saneamento básico, a entidade responsável pela regulação e fiscalização do serviço deve ser definida. Assim, poderá acontecer um aumento do número de entes/agências de regulação de saneamento básico no Brasil, pois, segundo dados da Agência Nacional de Águas e Saneamento Básico (ANA, 2020) (Tabela 2). existem 60 agências infranacionais atuando na área. No relatório da Associação Brasileira de Agência de Regulação (ABAR, 2017), consta que, naquele ano, 15 agências já possuíam a atribuição de regular/fiscalizar a componente drenagem urbana das águas pluviais.

\section{METODOLOGIA}

A estratégia metodológica utilizada para realização deste artigo, que se caracteriza como um estudo descritivo de base qualitativa $e$ quantitativa, adota um caráter de investigação com procedimentos de pesquisa bibliográfica e pesquisa documental.
Inicialmente, foi realizado um levantamento dos princípios, sistemas, dispositivos e normas empregadas para a drenagem e manejo de águas pluviais, com busca na bibliografia específica e artigos científicos obtidos pelo Portal de Periódicos da Capes e pelos dados e informações apurados no IBGE, SNIS e ABNT.

Também embasado em artigos e na bibliografia, relata-se a estrutura organizacional municipal comumente empregada na gestão das águas pluviais e detalham-se os instrumentos utilizados para gestão das águas.

Após o conteúdo obtido nesta etapa inicial de revisão bibliográfica, iniciou-se a busca de informações para o caso específico da gestão da drenagem de águas pluviais do município de Vitória, capital do Espírito Santo. A descrição da infraestrutura do sistema de drenagem do Município é relatada com base na análise documental do Plano Diretor de Drenagem de Urbana (PDDU). Na sequência, foram apuradas as principais legislações pertinentes à drenagem e manejo de águas pluviais no Município, com busca na Câmara de Vereadores.

A identificação da estrutura organizacional municipal envolvida com a drenagem é, também, 
efetuada com revisão documental, analisando a Lei municipal no 6.529/2005 (VITÓRIA, 2005), suas atualizações e decretos, para identificar a quais secretarias e setores são atribuídas as atividades relativas à drenagem e manejo de águas pluviais. Essas atribuições e setores, identificados nos decretos, em conjunto com a verificação das atividades efetivamente praticadas nas secretarias municipais, permitiram elaborar um organograma com todos os setores que atuam em drenagem urbana no Município.

O levantamento de pessoal por lotação, cargo e servidor dos setores envolvidos com a drenagem urbana foi efetuado no site Transparência Vitória, cujos dados foram transportados para uma planilha Excel, em que o tipo de vínculo, função e tempo de trabalho também foram considerados para análise. Com a observação de campo da atuação desses servidores, foi possível estabelecer o percentual de tempo mensal dedicado exclusivamente à atividade de drenagem, tendo em vista as demais atribuições estabelecidas para função desempenhada.
Para o levantamento dos recursos financeiros municipais e aqueles aplicados às atividades de drenagem urbana, recorreu-se ao site da transparência da prefeitura de Vitória, buscando os valores de receitas e despesas, dos contratos por secretaria e, principalmente, do orçamento previsto no Plano Plurianual (PPA) para o período de 2014 a 2017, limite temporal de contorno desta pesquisa. O Plano Plurianual (PPA) é previsto no artigo 165 da Constituição Federal e regulamentado pelo Decreto $\mathrm{n}^{\circ}$ 2.829/1998 (BRASIL, 1998) como um plano de médio prazo, que estabelece as diretrizes, objetivos e metas a serem seguidos pelo Governo Federal, Estadual e Municipal ao longo de um período de quatro anos.

Todos os valores desembolsados para a atividade de drenagem urbana foram analisados e comparados ao orçamento previsto no PPA 20142017, bem como às receitas e despesas municipais. Os contratos foram observados ainda com 0 propósito de se verificar os serviços executados.

Tabela 2: Agências de regulação de saneamento básico no Brasil

\begin{tabular}{|c|c|c|c|c|}
\hline $\begin{array}{c}\text { Agências } \\
\text { estaduais }\end{array}$ & $\begin{array}{c}\text { Agências de } \\
\text { consórcios } \\
\text { intermunicipais }\end{array}$ & $\begin{array}{c}\text { Agência } \\
\text { distrital }\end{array}$ & $\begin{array}{c}\text { Agências } \\
\text { municipais }\end{array}$ & Total \\
\hline 25 & 6 & 1 & 28 & 60 \\
\hline
\end{tabular}

Fonte: Elaboração própria a partir de dados da ANA (2020).

\section{RESULTADOS E DISCUSSÃO}

A gestão da drenagem urbana no município de Vitória, capital do estado do Espírito Santo, foi diagnosticada e analisada com relação à infraestrutura do sistema de drenagem implantado, aos aspectos legais vigentes, à estrutura organizacional em funcionamento, às características dos servidores/trabalhadores envolvidos, aos recursos financeiros aplicados e aos índices de desempenho utilizados.

\section{Infraestrutura do sistema de drenagem urbana implantada no município de Vitória/ES}

O município de Vitória/ES é formado por uma grande ilha e por uma porção continental.
Apresenta área territorial de $93,38 \mathrm{~km}^{2}$, altitude de $12 \mathrm{~m}$ e não possui zona rural. Tem como população estimada pelo IBGE (2019), 362.097 habitantes e densidade demográfica de $3.338,30 \mathrm{hab} . / \mathrm{km}^{2}$. A temperatura média da cidade varia entre $24,4^{\circ} \mathrm{C}$ e $34,4^{\circ} \mathrm{C}$, com temperaturas extremas registradas de $9,0^{\circ} \mathrm{C}$ e $39,6^{\circ} \mathrm{C}$, e apresenta uma média anual de pluviosidade de 1.103mm (INCAPER, 2019).

O Município foi contemplado pelo plano de Bacia Hidrográfica do Rio Santa Maria da Vitória elaborado em 2016 e é formado por um grande maciço central, com área de $10,05 \mathrm{~km}^{2}$, o que equivale a mais de $10 \%$ de sua área territorial. $\mathrm{A}$ cidade apresenta o maior manguezal urbano brasileiro com, aproximadamente, $11 \mathrm{~km}^{2}$ e possui mais de $12 \mathrm{~km}^{2}$ de aterros hidráulicos, ocorridos 
entre as décadas de 1830 e 1990. Aproximadamente $9 \mathrm{~km}^{2}$ desses aterros foram conquistados nas bordas da Cidade, e o restante, sobre o manguezal.

O Município elaborou o Plano Diretor de Drenagem Urbana (PDDU) em 2008, como parte do Plano Diretor Urbano (PDU-2006), com o objetivo de estabelecer ações de curto, médio e longo prazo, para reabilitar o sistema de drenagem urbana existente na Cidade, ampliar a cobertura do serviço e aumentar sua eficiência por meio da implantação de novas unidades operacionais e ações não estruturais.

Em 2014, o PDDU foi atualizado durante a elaboração do Plano Municipal de Saneamento Básico (PMSB-2016), sendo apresentado, em 2015, o Manual de Drenagem Urbana do Município de Vitória, como adendo ao seu produto 3. Constituíram-se, então, os principais instrumentos de gestão da drenagem e manejo de águas pluviais do município de Vitória (VITÓRIA, 2016b).

O PDDU identificou e cadastrou 98 bacias de drenagem por meio de levantamento cadastral das redes de drenagem existentes (Figura 2). Não foi utilizado o conceito de bacia hidrográfica, pois não há nenhum rio de curso natural na Cidade. Deste total, 29 bacias indicaram necessidade de ações estruturais.

O município de Vitória é composto por $632,83 \mathrm{~km}$ de vias pavimentadas e $285,48 \mathrm{~km}$ de redes de drenagem urbana. Do total destas redes, $60 \%$ são consideradas microdrenagem, ou seja, redes com diâmetro menor ou igual a $400 \mathrm{~mm}$, e $40 \%$ são redes tubulares com diâmetro variando entre 600 a $1.200 \mathrm{~mm}$ e galerias celulares com seções retangulares, consideradas como macrodrenagem, segundo o conceito adotado pelo PDDU do Município.

\section{Figura 2: Mapa com as Bacias de Drenagem de Vitória}

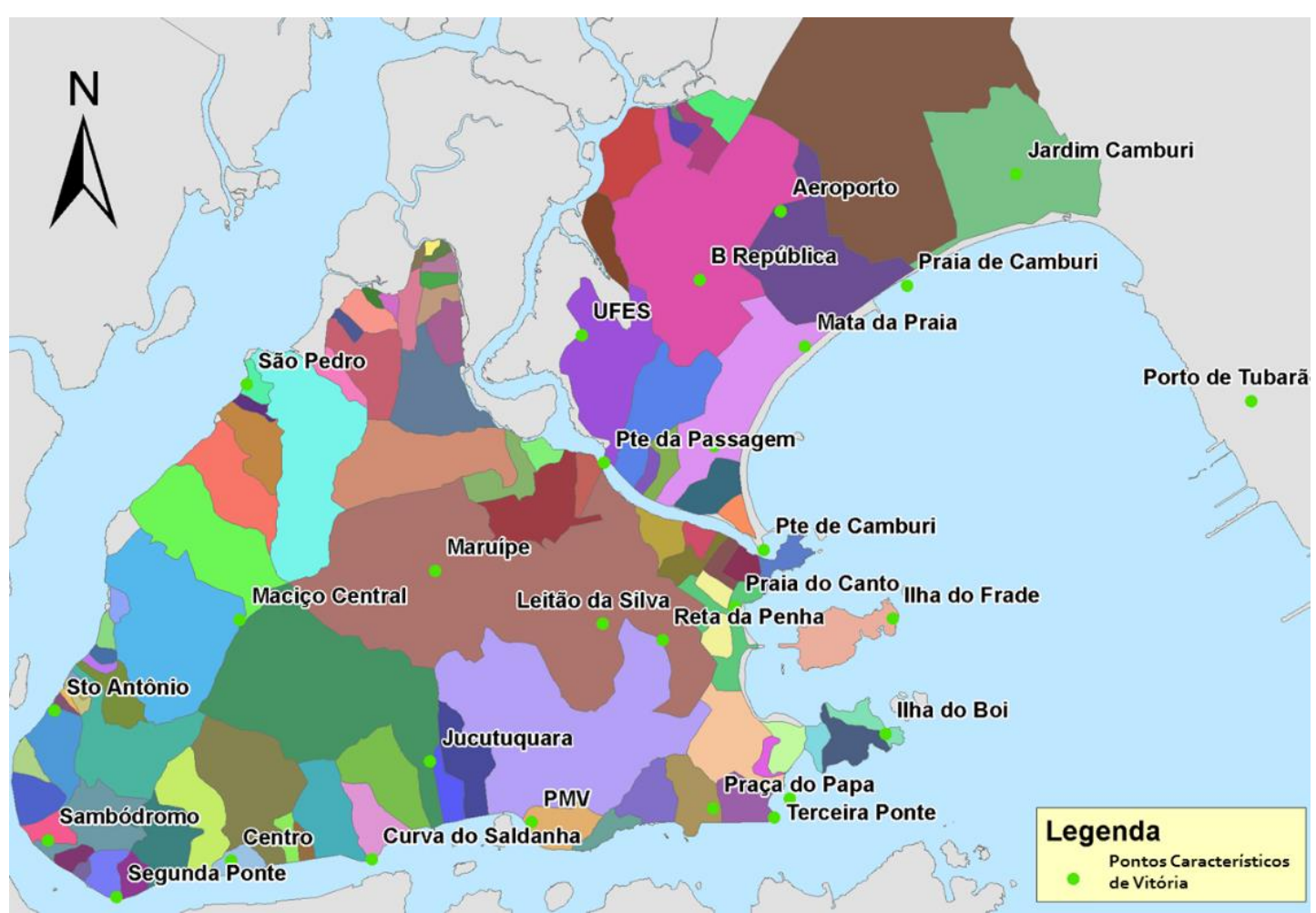

Fonte: Vitória (2009).

Além das redes, o sistema de drenagem do município de Vitória também é composto por 25.822 caixas-ralo, 3.555 poços de visita, 4 estações de bombeamento de águas pluviais localizadas no exutório de bacias, com capacidade de recalque de até $58,95 \mathrm{~m}^{3} / \mathrm{s}, 6$ 
reservatórios do tipo "in line" e 1 reservatório de amortecimento do tipo "off line", totalizando capacidade de armazenamento em $53.494,00 \mathrm{~m}^{3}$. Acrescenta-se que 0 monitoramento meteorológico é realizado por 10 estações pluviométricas distribuídas no território. A Figura 3 mostra o mapeamento de elementos da macrodrenagem.

Legislação municipal de Vitória com abordagem em drenagem e manejo de águas pluviais

A partir da análise das legislações constantes no Município, merece destaque a Lei no 8.062/2010 (VITÓRIA, 2010), que estabelece os parâmetros de dimensionamento do sistema de captação, armazenamento e destinação de águas pluviais, e especialmente o Plano Diretor Urbano (PDU) por meio da Lei $n^{\circ}=9.271 / 2018$ (VITÓRIA, 2018). Pela primeira vez, o PDU do Município contemplou a drenagem urbana em seus artigos 87 e 88 , estabelecendo, para as novas edificações e as edificações com acréscimos de área, o controle das águas de chuva com a implantação de sistema de captação, armazenamento e disposição em reservatórios. O artigo 89 da referida Lei acrescenta critérios para implantação de sistema de aproveitamento da água não potável, com volume, no mínimo, igual a $30 \%$ da capacidade do sistema de captação armazenamento e disposição (VITÓRIA, 2018).

\section{Figura 3: Mapa com cadastro das Redes de Macrodrenagem, Estações de Bombeamento} das Águas Pluviais (EBAP) e reservatórios de amortecimento de Vitória/ES

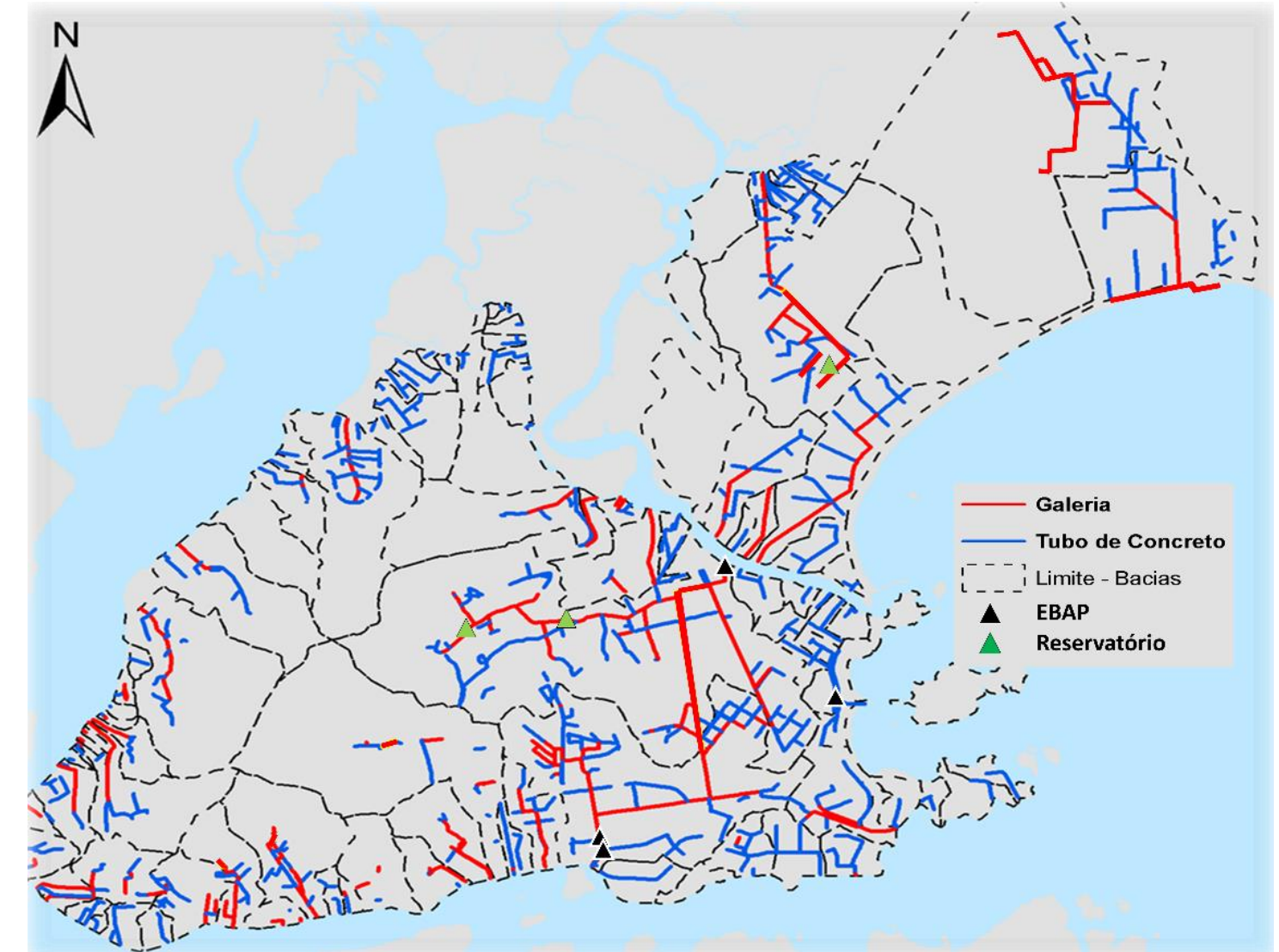

Fonte: Vitória (2009).

Tal postura representa um avanço para o Município, tendo em vista que há alguns anos tem se investido em obras de macrodrenagem que, com passar do tempo, se apresentam subdimensionadas, devido às impermeabilizações feitas nos lotes e que, por consequência, 
aumentam a vazão lançada nas redes de drenagem implantadas.

O Plano Diretor de Drenagem Urbana (PDDU) nunca foi instituído por meio de Lei ou Decreto, mas foi aprovado pelo Ministério das Cidades e atualizado no Plano Municipal de Saneamento Básico (PMSB), Lei no 8.945/2016, sendo utilizado pelo Município na captação de recursos federais para investimento nas ações estruturais indicadas pelo Plano (VITÓRIA, 2016b).

Legislações existentes em outros estados (SÃO PAULO, 2002) e citadas por Pereira et al. (2019) surgem como possibilidade de modelo para o município de Vitória avançar o arcabouço legal no controle do escoamento na fonte, com o aumento da permeabilidade e o reúso de águas pluviais.

Estrutura organizacional do município de Vitória com abordagem em drenagem e manejo de águas pluviais

A administração municipal direta e a estrutura de seus órgãos e unidades administrativas de Vitória/ES são redefinidas de acordo com suas atribuições apresentadas na forma da Lei municipal n 6.529/2005, com suas atualizações e decretos (VITÓRIA, 2005).

A Prefeitura Municipal de Vitória contempla, em 2019, uma estrutura organizacional composta pelo gabinete do prefeito, controladoria, procuradoria e mais 15 secretarias municipais, além de uma empresa pública municipal, denominada Companhia de Desenvolvimento, Turismo e Inovação de Vitória (CDTIV).

Nessa estrutura, as atribuições vigentes referentes à drenagem e manejo de águas pluviais são observadas em três secretarias: Secretaria de Obras e Habitação (SEMOHAB), Secretaria Central de Serviços e Secretaria de Meio Ambiente (SEMMAM).

A Secretaria Municipal de Obras e Habitação detém a maioria das atribuições referentes à gestão da drenagem urbana, realizando o planejamento, bem como contratando e elaborando projetos, conforme estabelecido nos planos (PDDU e PMSB), e executando obras. A Secretaria Central de Serviços é responsável pela operação, manutenção e reparo dos sistemas de drenagem com limpeza das redes, enquanto a Secretaria
Municipal de Meio Ambiente atua no monitoramento e controle da qualidade das águas pluviais lançadas nos corpos d'água pelas redes de drenagem. Dentro do organograma de cada uma dessas três secretarias, foram identificadas as unidades administrativas com essas atribuições voltadas à drenagem e manejo de águas pluviais.

O Decreto municipal no 16.993/2017 (VITÓRIA, 2017a) de criação da SEMOHAB indica que essa secretaria tem competência muito além da gestão de drenagem urbana, pois atribui à Subsecretaria de Execução de Obras a realização da gestão do saneamento básico no Município, inclusive com a relação com o Governo Estadual. Diante desta constatação, e sem questionar se esse tema de fato deveria ser de sua competência, essa Secretaria poderia ter em seu nome, a expressão "saneamento".

Dentre as atribuições aferidas à Subsecretaria de Execução de Obras, observa-se a de "definir e estruturar os sistemas de coleta, tratamento, guarda, recuperação e disseminação sistemática das informações sobre as atividades de interesse para o planejamento, monitoração e divulgação de indicadores de saneamento" (VITÓRIA, 2017a). De forma conflitante, o Comitê Gestor de Saneamento Básico do Município, criado em 01/03/2016 pelo Decreto Municipal $n^{\circ}$ 16.627/2016 (VITÓRIA, 2016a), na gestão anterior do mesmo prefeito, concorre com essa mesma atribuição, porém, sem registro de efetiva atuação.

A Gerência de Planejamento de Obras, identificada no organograma e vinculada à Subsecretaria de Execução de Obras, é a unidade administrativa com ações práticas mais direcionadas à drenagem urbana, embora não haja atribuição específica prescrita no Decreto $n$ 은 16.993/2017. No entanto, as ações efetivamente tomadas em relação à drenagem ocorrem na elaboração de projetos e na execução de obras de drenagem, conforme proposto no PMSB de 2014 (que atualizou o PDDU), sem ao menos dar a devida importância aos prazos por ele estabelecidos.

A Gerência de Execução de Obras, também vinculada à mesma Subsecretaria, apresenta algumas atribuições para drenagem estabelecidas pelo Decreto no 16.993/2017 (VITÓRIA, 2017a), assim como a Coordenação de Execução de Obras de Habitação, 
Infraestrutura e Edificações. Entretanto, na prática, se percebe ações mais voltadas a outros tipos de obras públicas, com nenhuma ou pouca ênfase na drenagem urbana.

O Decreto municipal o $17.000 / 2017$ (VITÓRIA, 2017c) e o Decreto municipal no 17.302/2018 (VITÓRIA, 2018b) atribuem competências para a Secretaria Central de Serviços, tendo a unidade administrativa de Assessoria Adjunta como a única que apresenta atribuição clara voltada para a drenagem urbana: "promover o assessoramento técnico gerencial dos projetos e das obras de manutenção de vias públicas, de drenagem e construção de pequenas redes" (VITÓRIA, 2018b).

Entretanto, o site da prefeitura amplia a responsabilidade dessa secretaria, que é encarregada das seguintes funções: coordenação dos serviços de atendimento aos munícipes nas regiões administrativas; manutenção de vias públicas; supervisão dos serviços de manutenção de drenagem; construção de pequenas extensões de rede; e execução dos serviços de conservação e reparos nos equipamentos urbanos.

$\mathrm{Na}$ prática, as operações e manutenções dos sistemas de drenagem da capital, são realizadas por essa secretaria por meio da subsecretaria de gestão da central de serviços, sua gerência de manutenção e respectiva coordenação, embora essas atribuições estejam vinculadas, conforme decretos citados, somente à secretaria adjunta.

Do organograma e das atribuições da SEMMAM, constata-se que, de acordo com o Decreto Municipal o 16.994/2017 (VITÓRIA, 2017b) e o Decreto municipal 17.301/2018 (VITÓRIA, 2018a), apenas a Coordenação de Monitoramento Atmosférico, Hídrico e do Solo apresenta competência para controlar monitoramentos hídricos e fiscalizar as ligações domiciliares ao sistema de drenagem pluvial.

As constatações de fragmentação das atribuições da drenagem urbana nos organogramas de três secretarias e a falta de integração das ações sobre o tema corroboram com a existência da fragilidade políticoadministrativa citada por Baptista e Nascimento (2002). Esses fatores, aliados à instituição por lei da Política de Saneamento Básico no Município (Lei Municipal o 8.945, de 13/05/2016) (VITÓRIA, 2016b), justificam a proposta de criação de uma estrutura unificada para a gestão da área de saneamento básico, abordando o componente de drenagem e manejo de águas pluviais.

Portanto, a administração pública direta é responsável pelos serviços de drenagem em Vitória, o que não se destoa do panorama nacional relativo à forma de prestação dos serviços de drenagem nas demais prefeituras brasileiras, conforme indicado na fundamentação teórica. Ressalta-se, ainda, a inexistência de agência reguladora para os serviços de drenagem do Município, embora a Agência de Regulação de Serviços Públicos do Estado (ASRP) atue na regulação dos serviços de água e esgoto prestados à cidade de Vitória.

\section{Composição da equipe municipal de Vitória atuante na drenagem e manejo de águas pluviais}

A prefeitura municipal de Vitória possui 13.108 servidores ativos. Deste total, aproximadamente, $77,0 \%$ atuam nas secretarias de educação (SEME) e de saúde (SEMUS), enquanto o restante dos servidores, $23 \%$, estão distribuídos nas outras unidades administrativas municipais.

Como referido, as três secretarias municipais com atribuições relativas à drenagem e manejo de águas pluviais são: SEMOHAB, Central de Serviço e SEMMMAM, conforme observado na Lei municipal $\mathrm{n}^{\circ}=6.529 / 2005$, atualizações e decretos (VITÓRIA, 2005).

No entanto, embora essas três secretarias juntas apresentem um total de 618 servidores, verifica-se que as atribuições relativas às questões de drenagem e manejo de águas pluviais urbanas foram conferidas apenas a alguns setores dessas secretarias.

Assim, consideram-se como equipe municipal atuante em drenagem e manejo de águas pluviais apenas aqueles servidores lotados nos setores cujas atribuições foram identificadas nos decretos municipais citados, incluindo aqui os respectivos superiores hierárquicos, perfazendo um total de 53 servidores, ou seja, $8,6 \%$ dos servidores das três secretarias mencionadas.

Destaca-se, ainda, que raramente os profissionais dos setores com atribuição relativa à drenagem e manejo de águas pluviais possuem dedicação exclusiva para essa função, pois distribuem seu tempo na realização das demais ações impostas pelos referidos decretos 
municipais.

Ao verificar o tipo de vínculo dessa equipe municipal atuante com drenagem e manejo de águas pluviais, constata-se que apenas 18,9\% são servidores efetivos, enquanto os servidores com cargos comissionados apresentam um percentual de $66,0 \%$, seguidos por estagiários e contratos por tempo determinado (Figura 4).

Considerando que o tempo de serviço na prefeitura implica em experiência adquirida no setor público, constata-se que $54,7 \%$ da equipe municipal atuante com drenagem e manejo de águas pluviais possuem menos de três anos no cargo, ou seja, entraram na prefeitura no período da gestão atual (2017-2020), enquanto na gestão anterior (2013-2016) ingressaram 26,4\% dessa equipe (Figura 5).

Considerando que a elaboração do PDDU foi realizada na gestão de 2005 a 2008, verificase que $92,5 \%$ da equipe municipal atuante com drenagem e manejo de águas pluviais não acompanharam o processo de preparação desse
Plano. Em outras palavras, apenas 4 (quatro) servidores da equipe atual de drenagem urbana vivenciaram o período de elaboração do PDDU. Esse fato tem efeito na continuidade das ações de drenagem, propiciando certa dificuldade de implementação do Plano, principalmente por não se ter realizado o programa previsto para divulgação e conhecimento desse importante instrumento de gestão da drenagem urbana.

Com uma visão mais apurada de cada um desses setores e considerando o levantamento de campo do percentual de horas mensais dedicados à efetiva atuação do servidor com a drenagem urbana, verifica-se de forma mais realista que a força de trabalho, para as atividades de drenagem urbana no Município, equivale a uma carga horária, correspondente a aproximadamente 9 (nove) servidores, de $140 \mathrm{~h} / \mathrm{mês}$ exclusiva para essas atividades.

\section{Figura 4: Gráfico com tipo de vínculo da equipe de servidores municipais atuantes com drenagem e manejo de águas pluviais (outubro, 2019)}

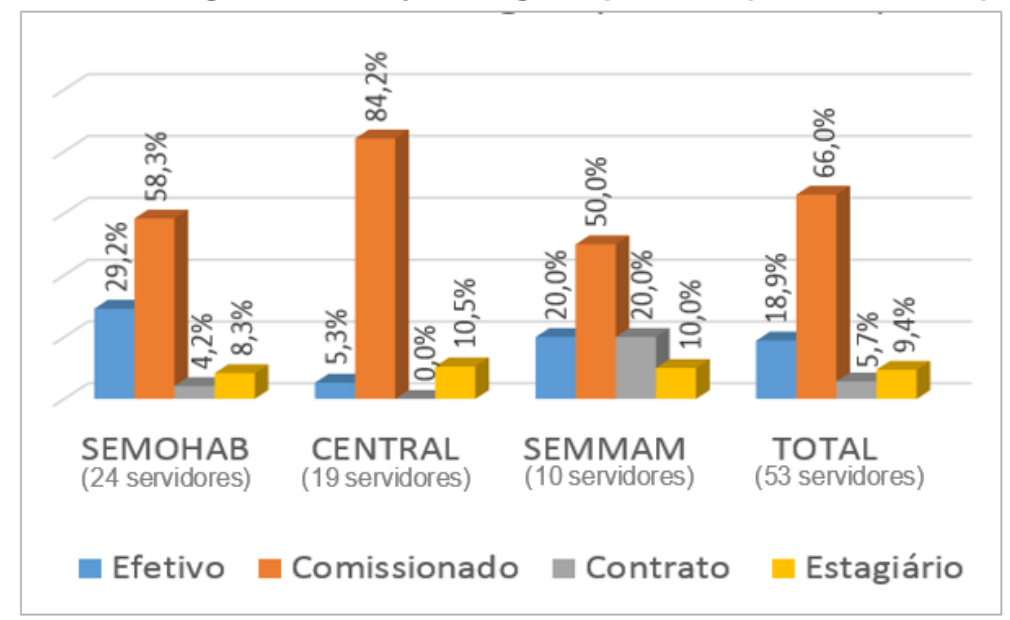

Fonte: Elaborado pelos autores a partir de Vitória (2019) (dados de outubro/2019).

Recursos financeiros para a drenagem e manejo de águas pluviais no município de Vitória

A gestão da drenagem urbana de qualquer município requer a implementação de medidas não estruturais e estruturais, como a elaboração de estudos e projetos, execução de obras de implantação, operação, recuperação e manutenção dos sistemas implantados, bem como o monitoramento.

Os recursos financeiros necessários para a realização dessas atividades consideram o custeio com material, mão-de-obra e equipamentos, que juntamente com os encargos e despesas indiretas formam o orçamento.

A partir de instrumentos de planejamento, tais como planos diretores, diretrizes ou normas internas, as prioridades de ações são 
estabelecidas com uma gestão orçamentária participativa para proposição do Plano Plurianual (PPA).

Considerando que o PPA 2018-2021 do município de Vitória está vigente, e ainda não há dados suficientes para sua avaliação conclusiva, avaliou-se o PPA do período anterior, ou seja, de 2014 a 2017, que foi estabelecido pela Lei $n^{\circ}$ 8.590/2013 e modificado pela Lei ำ 8.783/2014 (VITÓRIA, 2013; 2014), sendo composto por 38 programas que abarcam um total de 356 ações.

O "Programa 30 - Saneamento Ambiental Integrado" tem por objetivo realizar 12 ações integradas e estruturantes em saneamento ambiental (água, esgoto, drenagem urbana e resíduos sólidos) no Município, com previsão financeira de $\mathrm{R} \$ 597.104 .162,00$.

Dentre as ações desse programa, cinco abordam os componentes drenagem e manejo de águas pluviais que, juntas, perfazem um total de $R \$ 258.057 .006,00$. Esse valor equivale a $43,22 \%$ dos recursos destinados ao "Programa 30 Saneamento Ambiental Integrado".

Ao verificar os valores empenhados, liquidados e pagos anualmente para cada ação do Programa 30 do PPA 2014-2017 em relação à drenagem urbana, constata-se que 0 total liquidado no período de vigência do PPA foi de $\mathrm{R} \$ 33.209 .691,2626$ (Tabela 3).

Ao analisar os contratos, verifica-se que esse valor liquidado foi empregado em operação e manutenção de $\operatorname{EBAP}(34,7 \%)$, na limpeza de galerias e redes $(20,4 \%)$, em projetos $(3,3 \%)$, em obras de execução de reservatórios $(21,2 \%)$ e de drenagem da bacia Cândido Portinari (20,4\%), como mostrado na Figura 6.

Figura 5: Gráfico com ano de início dos servidores das equipes que atuam com drenagem e manejo de águas pluviais (outubro, 2019)

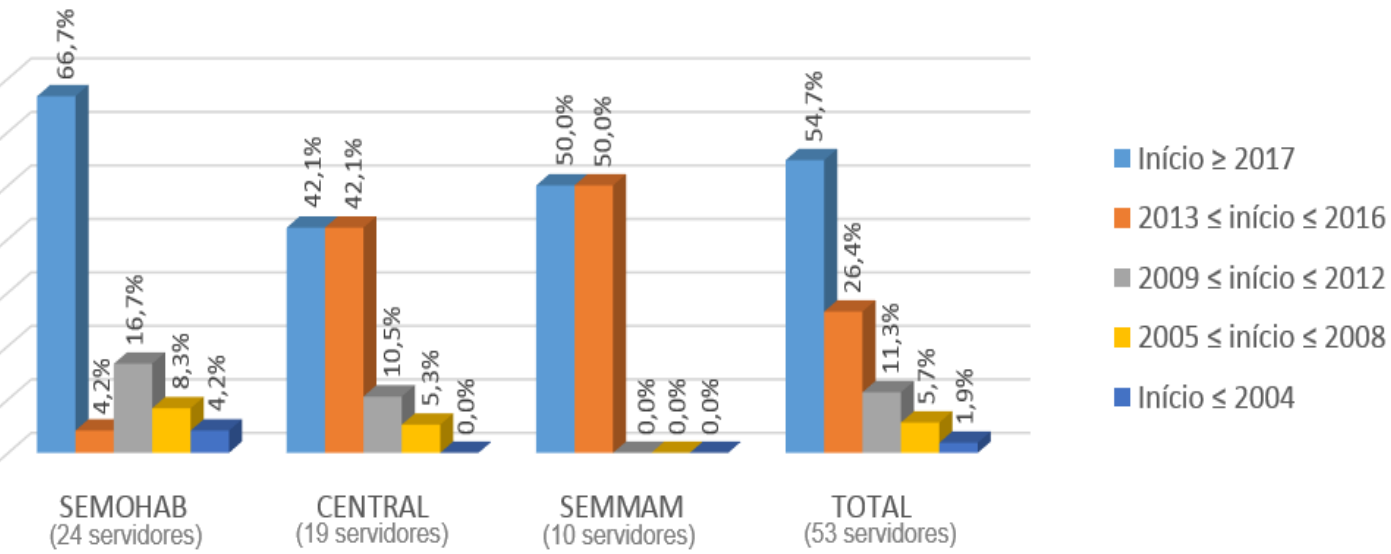

Fonte: Elaborada pelos autores a partir de Vitória (2019) (dados de outubro/2019).

Figura 6: Gráfico com porcentagem dos recursos financeiros aplicados por tipo de atividade de drenagem urbana realizada no período de 2014 a 2017

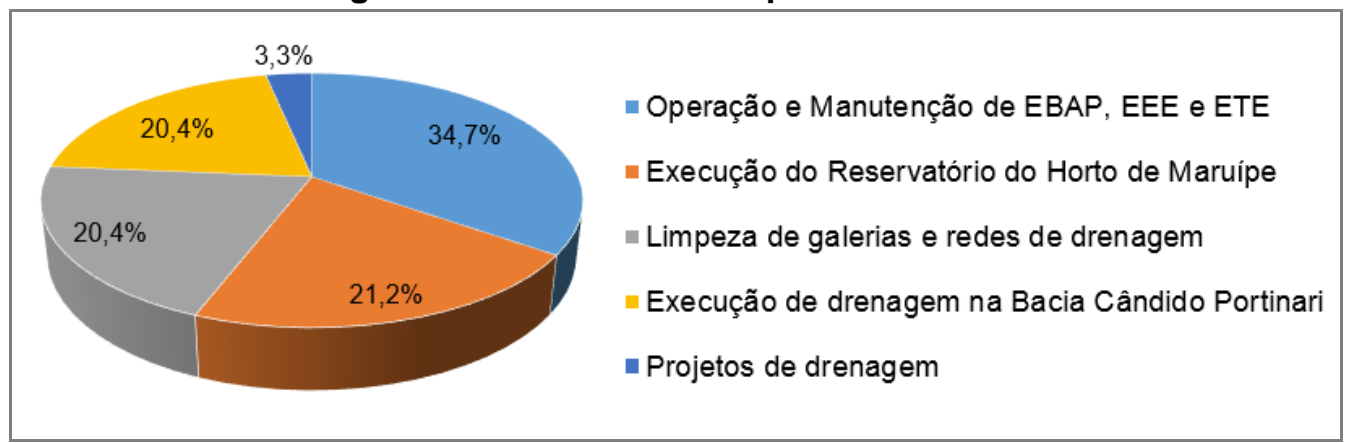

Fonte: Elaborada pelos autores a partir de Vitória (2019) (dados de outubro/2019). 
Portanto, a partir da transcrição dos valores de previsão orçamentária e a execução orçamentária anual das ações de drenagem do Programa 30 constantes no PPA 2014-2017 (Tabela 4), verifica-se que o percentual aplicado com a drenagem urbana no Município caiu drasticamente de 2015 para 2016, reduzindo o desembolso $38,99 \%$ para $2,75 \%$ do valor previsto.
Esse valor total liquidado na vigência do PPA 2014-2017, $\mathrm{R} \$$ 33.209.691,26, representa um percentual de $0,60 \%$ da receita municipal e $0,71 \%$ da despesa municipal incorrida no período, conforme mostrado na Tabela 4, na qual se verifica claramente que 0 valor destinado à drenagem urbana foi diminuindo durante $o$ período.

Tabela 3: Planilha de execução orçamentária das ações relacionadas à drenagem urbana do Programa 30 do PPA 2014-2017

\begin{tabular}{|c|c|c|c|c|c|c|c|}
\hline código & Ação & Execução Orçamentária & $\begin{array}{c}\text { Total } \\
\text { executado (R\$) }\end{array}$ & 2014 (R\$) & $2015(\mathrm{R} \$)$ & $2016(\mathrm{R} \$)$ & 2017 (R\$) \\
\hline \multirow{3}{*}{1287} & \multirow{3}{*}{ Implantação das obras previstas no PDDU } & Empenhado & $2.261 .426,62$ & $792.037,89$ & $521.242,76$ & $544.651,55$ & $403.494,42$ \\
\hline & & \begin{tabular}{|l|l|} 
Liquidado \\
\end{tabular} & $590.767,69$ & $122.466,18$ & $231.031,62$ & $237.269,89$ & 0,00 \\
\hline & & Pago & $523.146,01$ & $122.466,18$ & $163.409,94$ & $237.269,89$ & 0,00 \\
\hline \multirow{3}{*}{1288} & \multirow{3}{*}{$\begin{array}{c}\text { Intervenções nas Redes de Drenagem e } \\
\text { Esgotamento Sanitário }\end{array}$} & Empenhado & $15.688 .917,34$ & $14.848 .656,67$ & $757.585,94$ & $82.674,73$ & 0,00 \\
\hline & & \begin{tabular}{|l|l|} 
Liquidado \\
\end{tabular} & $13.716 .720,81$ & $13.022 .968,73$ & $611.077,35$ & $82.674,73$ & 0,00 \\
\hline & & Pago & $13.306 .454,59$ & $12.673 .772,06$ & $550.007,80$ & $82.674,73$ & 0,00 \\
\hline \multirow{3}{*}{1293} & \multirow{3}{*}{ Plano Municipal de Saneamento Básico } & Empenhado & $2.700 .905,23$ & $1.443 .749,26$ & $957.155,97$ & 0,00 & $300.000,00$ \\
\hline & & \begin{tabular}{|l|l} 
Liquidado \\
\end{tabular} & $883.072,55$ & $312.153,39$ & $303.048,37$ & 0,00 & $267.870,79$ \\
\hline & & \begin{tabular}{|l|} 
Pago \\
\end{tabular} & $615.201,76$ & $312.153,39$ & $303.048,37$ & 0,00 & $267.870,79$ \\
\hline \multirow{3}{*}{1296} & \multirow{3}{*}{ Plano Municipal de Manutenção de Redes } & Empenhado & 0,00 & 0,00 & 0,00 & 0,00 & 0,00 \\
\hline & & \begin{tabular}{|l|l} 
Liquidado \\
\end{tabular} & 0,00 & 0,00 & 0,00 & 0,00 & 0,00 \\
\hline & & Pago & 0,00 & 0,00 & 0,00 & 0,00 & 0,00 \\
\hline \multirow{6}{*}{2297} & \multirow{6}{*}{$\begin{array}{l}\text { Manutenção das Redes de Drenagem, } \\
\text { Operação e Manutenção das EEE, ETE e EBAP }\end{array}$} & Empenhado & $22.106 .596,51$ & $7.885 .797,31$ & $5.694 .263,51$ & $4.352 .171,48$ & $4.174 .364,21$ \\
\hline & & \begin{tabular}{|l|l|} 
Liquidado \\
\end{tabular} & $18.019 .130,21$ & $6.395 .296,98$ & $4.936 .821,02$ & $3.499 .598,74$ & $3.187 .413,47$ \\
\hline & & Pago & $15.663 .229,69$ & $6.027 .892,08$ & $3.252 .662,93$ & $3.195 .261,21$ & $3.187 .413,47$ \\
\hline & & Total Empenhado & $42.757 .845,70$ & $24.970 .241,13$ & $7.930 .248,18$ & $4.979 .497,76$ & $4.877 .858,63$ \\
\hline & & Total Liquidado & $33.209 .691,26$ & $19.852 .885,28$ & $6.081 .978,36$ & $3.819 .543,36$ & $3.455 .284,26$ \\
\hline & & Total Pago & $30.108 .032,05$ & $19.136 .283,71$ & $4.269 .129,04$ & $3.515 .205,83$ & $3.455 .284,26$ \\
\hline
\end{tabular}

Fonte: Elaborada pelos autores a partir de Vitória (2019) (dados de outubro/2019).

Tabela 4: Planilha de Previsão e Execução orçamentária anual com drenagem e respectivos percentuais de aplicação

\begin{tabular}{r|r|r|c|c|c}
\hline Ano & $\begin{array}{c}\text { Previsão } \\
\text { orçamentária } \\
\text { para drenagem } \\
\text { (R\$) }\end{array}$ & $\begin{array}{c}\text { Execução } \\
\text { orçamentária } \\
\text { em drenagem } \\
\mathbf{( R \$ )}\end{array}$ & $\begin{array}{c}\text { Percentual } \\
\text { aplicado em } \\
\text { drenagem } \\
\text { com relaçäo } \\
\text { ao previsto } \\
\mathbf{( \% )}\end{array}$ & $\begin{array}{c}\text { Percentual } \\
\text { aplicado em } \\
\text { drenagem } \\
\text { com relaçäo } \\
\text { a receita } \\
\text { municipal (\%) }\end{array}$ & $\begin{array}{c}\text { Percentual } \\
\text { aplicado em } \\
\text { drenagem } \\
\text { com relação } \\
\text { a despesa } \\
\text { municipal (\%) }\end{array}$ \\
\hline 2014 & $41.791 .165,00$ & $19.852 .885,28$ & $47,50 \%$ & $1,38 \%$ & $1,60 \%$ \\
\hline 2015 & $15.597 .470,00$ & $6.081 .978,36$ & $38,99 \%$ & $0,44 \%$ & $0,52 \%$ \\
\hline 2016 & $138.749 .759,00$ & $3.819 .543,36$ & $2,75 \%$ & $0,28 \%$ & $0,34 \%$ \\
\hline 2017 & $61.918 .612,00$ & $3.455 .284,26$ & $5,58 \%$ & $0,25 \%$ & $0,30 \%$ \\
\hline Total & $\mathbf{2 5 8 . 0 5 7 . 0 0 6 , 0 0}$ & $\mathbf{3 3 . 2 0 9 . 6 9 1 , 2 6}$ & $\mathbf{1 2 , 8 7 \%}$ & $\mathbf{0 , 6 0 \%}$ & $\mathbf{0 , 7 1 \%}$ \\
\hline
\end{tabular}

Fonte: Elaborada pelos autores a partir de Vitória (2019) (dados de outubro/2019).

\section{CONCLUSÃO}

Com base no estudo apresentado, pode-se concluir que, em relação à infraestrutura do sistema de drenagem urbana no município de
Vitória:

- Há necessidade de atualização e complementação do cadastro da drenagem, elaborado em 2007, incluindo todas as redes executadas a posteriori e, 
inclusive, as menores de $600 \mathrm{~mm}$, que não foram cadastradas na ocasião;

- Das 29 bacias de drenagem referidas, no PDDU de 2009, como necessitárias de ações estruturais, os contratos permitiram aferir que os recursos financeiros aplicados contemplaram a realização de obras em 04 bacias e a elaboração de projetos em 20 bacias.

- O Município monitora e controla a qualidade das águas pluvial lançadas nos corpos d'água pelas redes de drenagem, tendo em vista os contratos e os relatórios atestados pela secretaria municipal de meio ambiente.

Em relação à legislação municipal vigente para as atividades de drenagem:

- Os instrumentos de gestão pública existentes em Vitória - PDDU, PMSB, Manual de Drenagem e o PDU atualizado em 2018 - representam um cumprimento legal do município e indicam um avanço no estabelecimento de diretrizes, ao considerar essa situação no panorama nacional e a inexistência de normas técnicas para a drenagem urbana;

- Ainda se faz necessário ao Município dispor de legislação específica para controle ao uso e ocupação das áreas de risco geológico e das áreas alagáveis, e propor legislações de incentivo à drenagem sustentável.

Em relação à estrutura organizacional municipal:

- Determinados setores encontram-se com ações efetivamente praticadas em desarmonia com os decretos de atribuição dos serviços, como é o caso da Assessoria Adjunta e a Gerência de Manutenção dos Serviços. Portanto, devem-se ajustar os referidos decretos, ampliando atribuições ou realinhando as ações desses setores;

- Em uma visão mais ampla, a fragmentação das atribuições de drenagem em setores de secretarias distintas gera conflito com as presunções da Política de Saneamento Básico (Lei Municipal $\mathrm{n}^{\circ} \mathbf{0} 8.945$ de 13/05/2016), fazendo jus à proposta de implementação de uma estrutura única para a gestão da área de saneamento básico, seja em nível de secretaria ou, até mesmo, como uma autarquia municipal. Em todo caso, deve-se também dispensar atenção à necessidade de regulação, fiscalização e às diferentes formas de prestação dos serviços.

Em relação à composição da equipe técnica e capacidade administrativa municipal para as atividades de drenagem urbana, concluise que:

- Dos 13.108 servidores municipais, 618 estão lotados nas secretarias com atribuições para drenagem e manejo de águas pluviais. No entanto, 53 servidores possuem algum percentual de tempo envolvido com essas atribuições, que, realizando uma ponderação, equivale à carga horária correspondente a, aproximadamente, nove servidores com dedicação de 140h/mês; embora, na prática, apenas dois servidores possuem dedicação exclusiva para ações de drenagem e manejo de águas pluviais;

- Apenas quatro servidores da equipe atual de drenagem urbana da prefeitura vivenciaram o período de elaboração do PDDU em 2007. Esse fato indica efeito negativo na continuidade das ações de drenagem urbana;

- O Município deverá reestruturar a equipe de drenagem, de forma que a mesma seja adequada às necessidades da gestão do município.

Em relação aos recursos financeiros aplicados com as atividades de drenagem urbana, conclui-se que:

- Apenas $12,9 \%$ dos recursos financeiros previstos para drenagem urbana no PPA 2014-2017 foram utilizados, o que pode mostrar as dificuldades na gestão dos recursos, sendo que os valores destinados à elaboração do Plano de Manutenção de Redes, previstos no PDDU, nem foram utilizados;

- O desembolso com a drenagem urbana no período de vigência do PPA 20142017 representa um percentual de $0,60 \%$ da receita municipal e $0,71 \%$ da despesa municipal incorrida no período, indicando que 0 valor destinado à drenagem 
diminuiu durante o período, embora as ações estruturais estabelecidas no PDDU ainda encontram-se pendentes.

Por fim, embora a infraestrutura de drenagem urbana implantada em Vitória possa ser considerada adequada e bem direcionada pelos planos elaborados, observa-se a necessidade de avanço na implementação de medidas não estruturais e na adoção de legislações de incentivo aos sistemas sustentáveis. A melhoria fundamental encontra-se na reestruturação organizacional para uma gestão menos fragmentada e com uma equipe que atenda aos requisitos de quantidade, qualidade e menos rotatividade dos servidores, permitindo maior empenho na captação e aplicação dos recursos financeiros para cumprimento do planejamento estabelecido nos instrumentos de gestão.

\section{REFERÊNCIAS}

ABAR - Associação Brasileira de Agência de Regulação. Saneamento básico Regulação, 2017. Disponível em: http://abar.org.br/wpcontent/uploads/2017/09/ABAR_2017.pdf. Acesso em: 30 out. 2019.

ABNT - Associação Brasileira de Normas técnicas. ABNT Catálogo, c2019. Disponível em: https://www.abntcatalogo.com.br/normagrid.aspx.

Acesso em: 30 out. 2019.

AGERH - Agência Estadual de Recursos Hídricos do Espírito Santo. Planos de Bacias Hidrográficas e Enquadramento. Disponível em: https://agerh.es.gov.br/planos-enquadramento. Acesso em: 05 mar. 2020.

AGOSTINHO, M.S.P.; POLETO, C. Sistemas sustentáveis de drenagem urbana: dispositivos. Holos Environment, v. 12, n. 2, p. 121-130, 2012.

ANA - Agência Nacional de Águas e Saneamento Básico. Agências Reguladoras infranacionais. Disponível em:

https://www.ana.gov.br/saneamento/agencias-

reguladoras-subnacionais/ agencias-reguladorassubnacionais. Acesso em: 10 mai. 2020.

ANDRADE, A.; ROSSETTI, J.P. Governança corporativa: fundamentos, desenvolvimento e tendências. São Paulo: Atlas, 2006.
BAPTISTA, M.; NASCIMENTO, N. Aspectos institucionais e de financiamento dos sistemas de drenagem urbana. Revista Brasileira de Recursos Hídricos, v. 7, n. 1, p. 29-49, 2002.

BARBIERI, A. Delegação do serviço público. Revista Jus Navigandi, 2016 Disponível em: https://jus.com.br/artigos/52029/delegacao-do-servicopublico. Acesso em: 20 jul. 2020.

BRASIL, Ministério do Planejamento e Orçamento, Secretaria de Política Urbana. Regulação da Prestação de Serviços de Saneamento: Análise comparada da Legislação Internacional / $\mathrm{NH}$ Consultoria e Planejamento. (Série Modernização do Setor de Saneamento). Brasília, DF: Instituto de Pesquisa Econômica Aplicada, 1995.

Decreto federal no 2.829 , de 29 de outubro de 1998. Estabelece normas para a elaboração e a execução do Plano Plurianual e dos Orçamentos da União, e dá outras providências. Brasília, DF, 1998.

Lei no 8.666, de 21 de junho de 1993. Regulamenta 0 art. 37 , inciso $\mathrm{XXI}$, da Constituição Federal, institui normas para licitações e contratos da Administração Pública e dá outras providências. Brasília, DF, 1993.

Lei $\mathrm{n}$ - 8.987, de 13 de fevereiro de 1995. Dispõe sobre o regime de concessão e permissão da prestação de serviços públicos, previsto no art. $175 \mathrm{da}$ Constituição Federal, e dá outras providências. Brasília, DF, 1995.

Lei $\mathrm{n}$ - 9.433, de 08 de janeiro de 1997. Institui a Política Nacional de Recursos Hídricos, cria o Sistema Nacional de Gerenciamento de Recursos Hídricos, regulamenta 0 inciso XIX do art. 21 da Constituição Federal, e altera 0 art. $1^{\circ}$ da Lei $n^{\circ}$ 8.001, de 13 de março de 1990, que modificou a Lei no 7.990, de 28 de dezembro de 1989. Brasília, DF, 1997.

Lei $n$ ㅇ 11.079, de 30 de dezembro de 2004. Institui normas gerais para licitação e contratação de parceria público-privada no âmbito da administração pública. Brasília, DF, 2004.

Lei no 11.107, de 06 de abril de 2005. Dispõe sobre normas gerais de contratação de consórcios públicos e dá outras providências. Brasília, DF, 2005.

Lei no 11.445, de 05 de janeiro de 2007 . Estabelece as diretrizes nacionais para o saneamento básico e cria o Comitê interministerial de saneamento básico. Brasília, DF, 2007. 
CHIAVENATO, I. Administração: teoria, processo e prática. 4. ed. Rio de Janeiro: Elsevier Editora Ltda., 2007.

CHRISTOFIDIS, D.; ASSUMPÇÃO, R.S.F.V.; KLIGERMAN, D.C. A evolução histórica da drenagem urbana: da drenagem tradicional à sintonia com a natureza. Saúde em debate, v. 43, p. 94-108, 2019.

CRUZ, M.A.S.; SOUZA, C.F.; TUCCI, C.E.M. Controle da drenagem urbana no Brasil: avanços e mecanismos para sua sustentabilidade. In: SIMPÓSIO BRASILEIRO DE RECURSOS HÍDRICOS, 15., 2007, São Paulo. Anais... Porto Alegre: ABRH, 2007.

ESPÍRITO SANTO. Lei no $\mathbf{1 0 . 1 7 9}$ de $\mathbf{1 8}$ de março de 2014. Dispõe sobre a Política Estadual de Recursos Hídricos, institui o Sistema Integrado de Gerenciamento de Recursos Hídricos do Estado do Espírito Santo SIGERH/ES e dá outras providências. D.I.O. de 18 mar. 2014. Vitória, 2014.

FARIA, R.C.; FARIA, S.A.; MOREIRA, T.B.S. A privatização no setor de saneamento tem melhorado a performance dos serviços? Planejamento e Políticas Públicas, n. 28, p.7-21, jun./dez. 2005.

IBGE. Perfil de Informações Básicas Municipais Perfil dos municípios brasileiros: 2018. Rio de Janeiro, 2019.

INCAPER - Instituto Capixaba de Pesquisa, Assistência Técnica e Extensão Rural. Gráficos da Série Histórica - Vitória/ES. Disponível em: https://meteorologia.incaper.es.gov.br/graficos-da-seriehistorica-vitoria. Acesso em: 10 mai. 2019.

MARTINS, J.R.S. Gestão da drenagem urbana: só tecnologia será suficiente? São Paulo: Escola Politécnica, Universidade de São Paulo, 2012.

MIGUEZ, M.G.; REZENDE, O.M.; VERÓL, A.P. Drenagem urbana: do projeto tradicional à sustentabilidade. 1. ed. Rio de Janeiro: Elsevier Editora Ltda., 2015.

NEVES, M.G.F.P.; TUCCI, C.E.M. Composição de resíduos de varrição e resíduos carreados pela rede de drenagem, em uma bacia hidrográfica urbana. Revista Engenharia Sanitária e Ambiental, ABES, v. 16, p. 331-336, 2011.

NUVOLARI, A. (coord.). Esgoto sanitário: coleta, transporte, tratamento e reuso agrícola. 2. ed. São Paulo: Editora Blucher, 2011.
PEREIRA, L.C.O.; VIANA, E.M.; BRAGA, C.F.C. Estudo das legislações sobre drenagem urbana nas capitais do nordeste brasileiro: análise da obrigatoriedade de medidas de controle de escoamento na fonte. In: CONGRESSO INTERNACIONAL DE MEIO AMBIENTE E SOCIEDADE, I., 2019, Campina Grande. Anais... Campina Grande-PB: CEMEP, 2019.

POLETO, C. SUDS (Sustainable Urban Drainage Systems): Uma contextualização Histórica. Revista Thema, v. 8, n. 1, p. 1-10, 2011.

RIGHETTO, A.M. (coord.). Manejo de águas pluviais urbanas. Projeto PROSAB. Rio de Janeiro, ABES, 2009.

SANTOS, D.C. Saneamento para a gestão integrada das águas urbanas. 1. ed. Rio de Janeiro: Elsevier Editora Ltda., 2016.

SÃO PAULO. Lei Municipal n. o 13.276, de 04 de janeiro de 2002. Torna obrigatória a execução de reservatório para as águas coletadas por coberturas e pavimentos nos lotes, edificados ou não, que tenham área impermeabilizada superior a $500 \mathrm{~m}^{2}$. Diário Oficial do Município, de 04 de janeiro de 2002. São Paulo, 2002.

SNIS-AP - Sistema Nacional de Informações sobre Saneamento - Águas Pluviais. Diagnóstico de Drenagem e Manejo das Águas Pluviais Urbanas, 2018. Disponível em: http://www.snis.gov.br/diagnosticos/aguas-pluviais.

Acesso em: 17 out. 2019

SOUZA, C.F.; CRUZ, M.A.S.; TUCCI, C.E.M. Desenvolvimento urbano de baixo impacto: planejamento e tecnologias verdes para a sustentabilidade das águas Urbanas. Revista Brasileira de Recursos Hídricos, $A B R H$, v. 17, n. 2, p. 9-18, 2012.

SOUZA, M.L. Mudar a cidade: uma introdução crítica ao planejamento e à gestão urbanos. Rio de Janeiro: Bertrand Brasil, 2002.

SOUZA, V.C.B.S. Gestão da drenagem urbana no Brasil: desafios para a sustentabilidade. Revista Eletrônica de Gestão e Tecnologias Ambientais (Gesta), v. 1, n. 1 p. 057-072, 2013.

TUCCI, C.E.M.; HESPANHOL, I.; NETTO, O.M.C. Gestão da água no Brasil. Brasília: UNESCO, 2001.

A necessidade do planejamento da drenagem urbana. In: ; MARQUES, D.M.L.M. Avaliação 
e Controle da Drenagem Urbana. Porto Alegre: Editora UFRGS, 2000.

Gestão da drenagem urbana. Textos para discussão CEPAL/IPEA. Brasília, 2012.

Gestão de águas pluviais urbanas. Brasília: Ministério das Cidades, Global Water Partnership, World Bank, Unesco, 2005.

VITÓRIA. Decreto Municipal no 16.627, de 01 de março de 2016. Institui o Comitê Gestor de Saneamento Básico do Município de Vitória e dá outras providências. D.O.M. de 02 mar. 2016. Vitória, 2016a.

Decreto Municipal no 16.993, de 28 de março de 2017. Estabelece a forma de organização e regulamenta o funcionamento das Unidades Administrativas da Secretaria de Obras e Habitação e dá outras providências. D.O.M. de 30 mar. 2017. Vitória, 2017a.

Decreto Municipal no 16.994, de 28 de março de 2017. Estabelece a forma de organização e regulamenta 0 funcionamento das Unidades Administrativas da Secretaria de Meio Ambiente e Serviços Urbanos e dá outras providências. D.O.M. de 30 mar. 2017. Vitória, 2017b.

Decreto Municipal no $\mathbf{1 7 . 0 0 0}$, de 30 de março de 2017. Estabelece a forma de organização e regulamenta 0 funcionamento das Unidades Administrativas da Central de Serviços e dá outras providências. D.O.M. de 05 abr. 2017. Vitória, 2017c.

Decreto Municipal no 17.301, de 08 de fevereiro de 2018. Altera o Decreto $n^{\circ} 16.994$, de 28 de março de 2017, que dispõe sobre a organização e o funcionamento das unidades administrativas da Secretaria de Meio Ambiente e dá outras providências. D.O.M. de 09 fev. 2018. Vitória, 2018a.

Decreto Municipal no 17.302, de 08 de fevereiro de 2018. Altera o Decreto $n^{\circ} 17.000$, de 30 de março de 2017, que dispõe sobre a organização e o funcionamento das unidades administrativas da Central de Serviços e dá outras providências. D.O.M. de 09 fev. 2018. Vitória, 2018b.

Lei no $\mathbf{6 . 5 2 9}$, de 29 de dezembro de 2005 . Dispõe sobre adequações da estrutura organizacional da Prefeitura Municipal de Vitória e dá outras providências. A Tribuna de 01 jan. 2006. Vitória, 2006.

Lei no 8.062, de 29 de dezembro de 2010 . Dispõe sobre os parâmetros de dimensionamento do sistema de captação, armazenamento e destinação de águas pluviais, estabelecido pelo Art. 154 de Lei $\mathrm{n}^{\circ}$ 6.705 , de 13 de outubro de 2006. A Tribuna de $31 \mathrm{dez}$. 2010. Vitória, 2010.

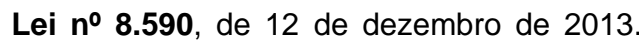
Dispõe sobre o Plano Plurianual - PPA para o período 2014/2017. D.I.O. de 13 dez. 2013. Vitória, 2013.

Lei no 8.783, de 30 de dezembro de 2014 . Dispõe sobre a revisão do Plano Plurianual - PPA, referente 2014/2017, instituído pela Lei no 8.590, de 12 de dezembro de 2013, conforme determina os Arts. 3은 e $4^{\circ}$ da mesma Lei. D.O.M. de 31 dez. 2014. Vitória, 2014.

Lei no 8.945, de 10 de maio de 2016. Aprova o Plano Municipal de Saneamento Básico do Município de Vitória, e autoriza celebração de convênio. D.O.M. de 13 mai. 2016. Vitória, 2016b.

VITÓRIA. Lei no 9.271, de 21 de maio de 2018. Aprova o Plano Diretor Urbano (PDU) do Município de Vitória. D.O.M. de 22 mai. 2018. Vitória, 2018.

Plano Diretor de Drenagem Urbana (PDDU). Vitória: Prefeitura Municipal de Vitória. 2009.

VITÓRIA. Portal Transparência Vitória. Disponível em: http://transparencia.vitoria.es.gov.br/ Acesso em: 30 dez. 2019. 